\title{
Enrichment of Chappathi with Shade Dried Moringa olifera Flower Powder using Response Surface Methodology (RSM)
}

\author{
P. Nazni* and J. Gracia \\ Department of Food Science and Nutrition, Periyar University, Salem, Tamil Nadu, India; \\ naznip@gmail.com, jgraciab@gmail.com
}

\begin{abstract}
Moringa is free flowering, generally occurs 4-12 months after planting, depending on the type. The Moringa olifera was used in treating cold, anaemia, tumor, diuretic, and contain powerful antibiotic which has fungicidal properties. Whole wheat flour is mainly used for preparation of Chappathi. Hence the present study is undertaken to process drumstick flower into powder and analyzing the physiochemical properties and nutritive value and optimization of wheat flour and Shade Dried Drumstick Flower Powder (SHD-DFP) using Response Surface Methodology (RSM) for acceptable Chappathi considering diameter, cooking time, weight, kneading time and overall acceptability as a response variables. Results revealed that, RSM was applied for optimization, the multiple regression was used to get optimum levels and it was found that desirable values of diameter $(15.19 \mathrm{~cm})$, cooking time $(1.52 \mathrm{~min})$, weight $(100.41 \mathrm{gm})$, kneading time $(5.14 \mathrm{~min})$ and overall acceptability (7) was obtained for optimum condition of wheat flour (100gm) and SHD-DFP (5gm). Hence it is concluded that RSM was used successfully to optimize the level of wheat flour and SHD-DFP for the development of value added chappathi.
\end{abstract}

Keywords: Moringa olifera Flowers and Leaves, Optimization, Physiochemical Properties, Response Surface Methodology

\section{Introduction}

Moringa oleifera, commonly referred to simply as "Moringa" is the most widely cultivated species of the genus Moringa. Moringa olifera flowers and leaves are good source of protein. Drumstick flowers have been reported to be a rich source of carotene, protein, vitamin C, calcium and potassium and act as a good source of natural antioxidants and thus enhance the shelf-life of fat containing foods due to the presence of various types of antioxidant compounds such as ascorbic acid, flavonoids, phenolics and carotenoids [1]. The drumstick flowers can be eaten or used as a garnish and look most decorative in salads [2]. Moringa oleifera flowers have seven times more vitamin C than oranges to fight many illnesses including cold and flu. Moringa oleifera are four times more vitamin A than carrots to protect against eye disease, skin disease, and heart disease. Moringa oleifera flowers are four times more calcium than milk to build strong bones and teeth. They are three times more potassium than bananas essential for the functioning of the brain and nerves. Nearly 2 times the protein in milk and almost equal amounts of proteins as in eggs basic building blocks of all our body cells [3].

The word Dehydration means removing water or moisture from foods. Drying is the oldest known method of preserving food. Historically, food was dried in the sun. Nowadays, we can sundry or dry in an oven or a dehydrator that is especially designed for home drying [4].

Among the various types of processing techniques dehydration is considered to be an inexpensive method and imparts properties that are unmatched by any other preservation technique [5].

Wheat is one of the staple foods of the majority of Indian population. Whole wheat flour is mainly used

*Author for correspondence 
for preparation of chappathi and other traditional indigenous products of wheat flour origin are poories, naans, kulchas, bathuras and so on [6]. The Response Surface Methodology (RSM) is a useful technique, for the investigation of complex processes. It has been successfully applied to optimize food process operations [7]. RSM is an effective statistical technique of process optimization [8]. The present study was undertaken with the objective to process drumstick flower into powder and analyzing the physiochemical properties of the powder and determine the optimal levels of wheat flour and shade dried drumstick flower powder (SHD-DFP) for acceptable Chappathi.

\section{Materials and Methods}

\subsection{Sources of Materials}

Wheat flour and salt were purchased from the local market in Salem, Tamil Nadu, India and checked for its purity. The drumstick flowers were collected freshly. It was blanched in just enough boiling water for 2-3 minutes, removed immediately and spread on muslin cloth/trays for drying. Then the drumstick flowers were loaded on the oven trays forming one single layer of the dehydrator and were dried in the dehydrator by forced air technique. Then the drumstick flowers were shade dried until done. The temperature was maintained at $60^{\circ} \mathrm{C}$. Drumstick flowers were sufficiently dried till they became crisp and brittle to touch. The drumstick flowers took four to five hours for complete drying. The Shade Dried - Drumstick Flower Powder (SHD-DFP) was packed in low density polyethylene bag and stored in the refrigerator until required.

\subsection{Analysis of Physiochemical Properties of Selected SHD-DFP}

Physical properties such as the drying ratio and rehydration ratio were calculated by the method of Ranganna [9]. The water absorption capacity and oil absorption capacity was determined by the method of Sathe et al. [10] and the bulk density of the SHD-DFP as determined using Ige, 1984 [11]. The chemical properties such as moisture, total ash and fibre were determined using AOAC method [12]. The carbohydrate was assessed using Anthrone method and the total carotene was determined using spectrophotometer. All the estimations were done in triplicates.
The anti-nutritional substances suspected to be present namely tannin was analyzed using Folin Denis Method.

\subsection{Preparation of SHD-DFP Incorporated Chappathi}

Required amount (90-100g) of wheat flour was mixed with required amount $(5-15 \mathrm{~g})$ of SHD-DFP and made into dough by adding salt and water. Then divide it into separate balls, thin it in roll board and pin. Heat the tawa and cook till it was done.

\subsection{Experimental Design for Optimization SHD-DFP Incorporated Chappathi}

The Response Surface Methodology (RSM) is a widely adopted tool for the quality of optimizations processes [13]. The RSM, originally described by Box and Wilson (1951) is effective for responses that affect many factors and their interactions. The Central Composite Rotatable composite Design (CCRD) was adopted to predict responses based on few sets of experimental data in which all factors were varied within a chosen range. Response surface methodology was applied to the experimental data using a commercial statistical package (Design expert, Trial version 6.0, State Ease Inc., Minneapolis, IN statistical software) for the generation of response surface plot and optimization of process variables. The experiments were conducted according to Central Composite Rotatable Design (CCRD) [14]. A $3^{2}$ factorial experiment was used to study the effects of Wheat flour $\left(\mathrm{X}_{1}\right)$ and Shade Dried Drumstick Flower Powder $\left(\mathrm{X}_{2}\right)$ on the Diameter $\left(\mathrm{Y}_{1}\right)$, Cooking time $\left(\mathrm{Y}_{2}\right)$, Weight $\left(\mathrm{Y}_{3}\right)$, Kneading time $\left(\mathrm{Y}_{4}\right)$ and Overall acceptability $\left(\mathrm{Y}_{5}\right)$ on Table 1 of the developed Chappathi.

Each design point consists of three replicates. For the statistical analysis the numerical levels are standardized to $-1,0$, and 1 . The experiments were carried out in randomized order [15]. The relationship between standardized variables values is given as follows.

$$
\begin{aligned}
& \mathrm{X}_{1}=\frac{\text { Wheat flour }-95}{5} \\
& \mathrm{X}_{2}=\frac{\text { SHD-DFP }-10}{5}
\end{aligned}
$$

The standard scores were fitted to a quadratic polynomial regression model for predicting individual $\mathrm{Y}$ responses by employing at least square technique $[16,17]$. 
Table 1. Process variables, their levels and experimental design

\begin{tabular}{|c|c|c|c|c|}
\hline \multirow[t]{2}{*}{ Variables } & \multirow[t]{2}{*}{ Symbols } & \multicolumn{3}{|c|}{ Coded value } \\
\hline & & -1 & 0 & +1 \\
\hline Wheat flour & $\mathrm{X}_{1}$ & 90 & 95 & 100 \\
\hline SHD-DFP & $\mathrm{X}_{2}$ & 5 & 10 & 15 \\
\hline Design point & Uncol & & & \\
\hline $\mathrm{V}_{1}$ & 90 & 5 & -1 & -1 \\
\hline $\mathrm{V}_{2}$ & 95 & 5 & 0 & -1 \\
\hline $\mathrm{V}_{3}$ & 100 & 5 & +1 & -1 \\
\hline $\mathrm{V}_{4}$ & 90 & 10 & -1 & 0 \\
\hline $\mathrm{V}_{5}$ & 95 & 10 & 0 & 0 \\
\hline $\mathrm{V}_{6}$ & 100 & 10 & +1 & 0 \\
\hline $\mathrm{V}_{7}$ & 90 & 15 & -1 & +1 \\
\hline $\mathrm{V}_{8}$ & 95 & 15 & 0 & +1 \\
\hline $\mathrm{V}_{9}$ & 100 & 15 & +1 & +1 \\
\hline $\mathrm{V}_{10}$ & 95 & 10 & 0 & 0 \\
\hline $\mathrm{V}_{11}$ & 95 & 10 & 0 & 0 \\
\hline $\mathrm{V}_{12}$ & 95 & 10 & 0 & 0 \\
\hline $\mathrm{V}_{13}$ & 95 & 10 & 0 & 0 \\
\hline
\end{tabular}

$\mathrm{X}_{1} \rightarrow$ Wheat flour $\mathrm{X}_{2} \rightarrow$ Shade dried drumstick flower powder

The second order polynomial equation was fitted to the experimental data of each dependent variable as given. The model proposed to each response of $Y$ was

$$
\mathrm{Y}=\beta_{0}+\sum_{\mathrm{i}=1}^{3} \beta_{\mathrm{i}} \mathrm{X}_{\mathrm{i}}+\sum_{\mathrm{i}=1}^{3} \beta_{\mathrm{ij}} \mathrm{X}_{\mathrm{i}^{2}}+\sum_{\mathrm{i}<\mathrm{j}=1}^{3} \beta_{\mathrm{ij}} \mathrm{X}_{\mathrm{i}} \mathrm{X}_{\mathrm{j}}
$$

The 3D response surface plot were generated for different interactions of any two independent variables, check holding the value of third variables as constant at the central level. The optimization of the process was aimed at finding the optimum values of independent variables (overall acceptability and omega 3 fatty acid). The optimum values of the selected variables were obtained by solving the regression equation.

\subsection{Analysis of Physiochemical Properties of Selected SHD-DFP Incorporated Chappathi}

Physical properties such as the drying ratio and rehydration ratio were calculated by the method of Ranganna [9]. The water absorption capacity and oil absorption capacity was determined by the method of Sathe et al, 1982 and the bulk density of the SHD-DFP as determined using
Ige [11]. The chemical properties such as moisture, total ash and fibre were determined using AOAC method. The carbohydrate was assessed using Anthrone method and the total carotene was determined using spectrophotometer. All the estimations were done in triplicates.

\subsection{Sensory Evaluation of SHD-DFP Incorporated Chappathi}

The sensory evaluation was carried out in order to get consumer response for overall acceptability of the drumstick flower powder compared to the control chappathi. Products were evaluated by a panel of 10 semi-trained judges for different sensory attributes like appearance, flavour, taste, texture and overall acceptability. To carry out the initial optimization of ingredients, the prepared formulation were judged by a trained panel of 15-member using a 9 point Hedonic rating (9-Like extremely and 1-dislike extremely) [18] for colour, texture, flavor and overall acceptability. A 9-point hedonic scale ranging from 1 to 9 , where $1=$ extremely dislike and $9=$ like was used to evaluate acceptability of sample. Data were subjected to analysis of variance (ANOVA) using the SPSS software and differences among means were compared using Duncan's Multiple Range test. A significance level of 0.05 was chosen. Information about the ingredients used in the prepared chappathi was revealed to the panelists after conclusion of the sensory evaluation exercise in order to evaluate the influence of health awareness on food selection by the panelists.

\subsection{Statistical analysis}

The experimental data were subjected to Analysis of Variance (ANOVA) to evaluate the effect of various treatments and their interactions on the response [19] using Design Expert-8.0 version. The analytical data obtained for shade dried drumstick flower powder were subjected to analysis of variance (ANOVA) (one way anova) using complete randomized design.

\section{Findings}

\subsection{Physical Characteristics of SHD-DFP}

The final yield of SHD-DFP for $100 \mathrm{~g}$ after drying was found to be $28 \mathrm{~g}$ with the moisture of $8.23 \%$. Regarding rehydration ratio $100 \mathrm{~g}$ of the SHD-DFP was found to be $14.86 \mathrm{~g}$ respectively. Contravention results was defined by 
$[20,21]$ who reported that oven drying $(1: 5)$ is the best when compared to sun drying (1:16.5) and shade drying respected of drying and dehydration ratio. The oil absorption capacity, water absorption capacity and bulk density of SHD-DFP were $5.4 \mathrm{ml}, 6.4 \mathrm{ml}$ and $6.9 \mathrm{gm}$ respectively. Similar to our study, Fagbemi [22] reported that the water absorption.

\subsection{Chemical Composition of SHD-DFP}

The nutrient content of SHD-DFP is reported as moisture $8.23 \%$, carbohydrate $35.50 \mathrm{gm}$, ash $6 \mathrm{gm}$, fiber $9.2 \mathrm{gm}$ and carotene $2.28 \mu \mathrm{g}$ respectively. The moisture content of the powder was low enough for its longer shelf life.

\subsection{Anti-nutritional Factor}

The anti-nutritional factor in the SHD-DFP such as tannin may be about $1.02 \mathrm{~g} / 100 \mathrm{~g}$ respectively. The tannin content of dehydrated drumstick flower was $1.8 \mathrm{~g} / 100 \mathrm{~g} 5$.

\subsection{Optimization of SHD-DFP Incorporated Chappathi}

The Chappathi prepared with the help of wheat flour and SHD-DFP was characterized for its physiochemical and organoleptic characteristics. The Diameter $\left(\mathrm{Y}_{1}\right)$, Cooking time $\left(\mathrm{Y}_{2}\right)$, Weight $\left(\mathrm{Y}_{3}\right)$, Kneading time $\left(\mathrm{Y}_{4}\right)$ and Overall acceptability $\left(\mathrm{Y}_{5}\right)$ were measured for response variables.
Table 2 shows that the diameter of chapatti may be ranged from 14.9 to $15.4 \mathrm{~cm}$, cooking time 1.42 to 1.59 minutes, weight 94.3 to $105.9 \mathrm{gm}$, kneading time 4.13 to 5.23 minutes and overall acceptability may range from 4 to 7 respectively.

\subsection{Regression Coefficient for the Response Variables}

The regression coefficient for the response variables were shown in Table 3.

The diameter of SHD-DFP incorporated Chappathi varied from 14.9 to $15.4 \mathrm{~cm}$ for the samples treated under different incorporation levels. The $\mathrm{R}^{2}$ value of the diameter of SHD-DFP chappathi was 0.84 for the regression model predicting the diameter, which shows $84 \%$ variability in the data. The cooking time of the SHD-DFP incorporated chappathi was 1.42 to 1.59 respectively. The kneading time of the SHD-DFP incorporated chappathi was $4.13 \mathrm{~min}$ to 5.23 respectively. The coefficient of determination, $\mathrm{R}^{2}$ for the regression model predicting the cooking time and the predicting the kneading time were 99\%. The data also indicated that the lack of fit is not significant. The weight of the chappathi varied from 94.3 to $105.9 \mathrm{~g}$. The coefficient of determination $\mathrm{R}^{2}$ was $81 \%$ for the regression model predicting the weight. The lack of fit is found to be not significant. The maximum overall acceptability is found to be 7 and it varied from 4 to 7 . The

Table 2. Physical and sensory properties of SHD-DFP incorporated Chappathi

\begin{tabular}{|c|c|c|c|c|c|c|c|}
\hline \multirow[t]{2}{*}{ Variables } & \multicolumn{2}{|c|}{ Uncoded value } & \multirow{2}{*}{$\begin{array}{l}\text { Diameter } \\
(\mathrm{cm})\end{array}$} & \multirow{2}{*}{$\begin{array}{l}\text { Cooking } \\
\text { time (min) }\end{array}$} & \multirow{2}{*}{$\begin{array}{c}\text { Weight } \\
\text { (kg) }\end{array}$} & \multirow{2}{*}{$\begin{array}{l}\text { Kneading } \\
\text { time (min) }\end{array}$} & \multirow{2}{*}{$\begin{array}{c}\text { Overall } \\
\text { acceptability }\end{array}$} \\
\hline & $\mathrm{X}_{1}$ & $\mathrm{X}_{2}$ & & & & & \\
\hline S & 100 & - & 15 & 1.4 & 95.1 & 4.13 & 7 \\
\hline $\mathrm{V}_{1}$ & 90 & 5 & 14.9 & 1.42 & 94.3 & 4.15 & 7 \\
\hline $\mathrm{V}_{2}$ & 95 & 5 & 15 & 1.4 & 94.8 & 4.22 & 6 \\
\hline $\mathrm{V}_{3}$ & 100 & 5 & 15.2 & 1.53 & 99.3 & 5.16 & 7 \\
\hline $\mathrm{V}_{4}$ & 90 & 10 & 14.9 & 1.44 & 94.5 & 4.37 & 5 \\
\hline $\mathrm{V}_{5}$ & 95 & 10 & 15.1 & 1.43 & 97.5 & 4.39 & 5 \\
\hline $\mathrm{V}_{6}$ & 100 & 10 & 15.3 & 1.56 & 105.9 & 5.19 & 6 \\
\hline $\mathrm{V}_{7}$ & 90 & 15 & 15.1 & 1.46 & 98.7 & 4.59 & 4 \\
\hline $\mathrm{V}_{8}$ & 95 & 15 & 15.2 & 1.47 & 99,6 & 4.54 & 4 \\
\hline $\mathrm{V}_{9}$ & 100 & 15 & 15.4 & 1.59 & 101.3 & 5.23 & 5 \\
\hline $\mathrm{V}_{10}$ & 95 & 10 & 15.2 & 1.44 & 98.4 & 4.39 & 6 \\
\hline $\mathrm{V}_{11}$ & 95 & 10 & 15.1 & 1.45 & 98.7 & 4.5 & 6 \\
\hline $\mathrm{V}_{12}$ & 95 & 10 & 15.1 & 1.44 & 98.4 & 4.39 & 7 \\
\hline $\mathrm{V}_{13}$ & 95 & 10 & 15.3 & 1.45 & 98.7 & 4.39 & 6 \\
\hline
\end{tabular}


Table 3. Regression coefficient for the response variables

\begin{tabular}{|c|c|c|c|c|c|}
\hline Coefficients & Diameter & $\begin{array}{l}\text { Cooking } \\
\text { time }\end{array}$ & Weight & $\begin{array}{l}\text { Kneading } \\
\text { time }\end{array}$ & $\begin{array}{c}\text { Overall } \\
\text { acceptability }\end{array}$ \\
\hline Model & 15.14 & 1.44 & 98.43 & 4.41 & 5.83 \\
\hline $\mathrm{X}_{1}$ & $0.18^{* *}$ & 0.06 & 3.17 & 0.41 & 0.33 \\
\hline $\mathrm{X}_{2}$ & -0.05 & 0.03 & 1.87 & 0.14 & -1.17 \\
\hline $\mathrm{X}_{1}^{2}$ & -0.06 & 0.06 & 1.54 & 0.38 & 0.10 \\
\hline $\mathrm{X}_{2}^{2}$ & 0.04 & -3.62 & -1.46 & -0.01 & -0.40 \\
\hline $\mathrm{X}_{1} \mathrm{X}_{2}$ & 0.00 & 5.00 & -0.60 & -0.09 & 0.25 \\
\hline $\mathrm{R}^{2}$ & 0.84 & 0.99 & 0.81 & 0.99 & 0.75 \\
\hline Adj $R^{2}$ & 0.72 & 0.98 & 0.67 & 0.99 & 0.56 \\
\hline Pred $\mathrm{R}^{2}$ & 0.49 & 0.95 & -0.84 & 0.98 & 0.06 \\
\hline Adeq $\mathrm{R}^{2}$ & 9.94 & 0.95 & 8.64 & 39.24 & 6.49 \\
\hline Std Dev & 0.08 & 7.99 & 1.75 & 0.04 & 0.68 \\
\hline
\end{tabular}

coefficient of determination $\mathrm{R}^{2}$ was $75 \%$ for the regression model predicting the overall acceptability.

\subsection{Mathematical Model for Optimization using Response Surface Methodology}

Mathematical relationship generated using Multiple Linear Regression Analysis for the response variable for coded and uncoded values are expressed in equation 1 to 5 .

\subsection{Coded Value}

$$
\begin{aligned}
\mathrm{Y}_{1}= & 15.14+0.17 \mathrm{X}_{1}+0.100 \mathrm{X}_{2}-6.897 \mathrm{X}_{1}^{2} \\
& -6.897 \mathrm{X}_{2}^{2}+0.00 \mathrm{X}_{1} * \mathrm{X}_{2} \\
\mathrm{Y}_{2}= & 1.44+0.060 \mathrm{X}_{1}+0.028 \mathrm{X}_{2}+0.061 \mathrm{X}_{1}^{2} \\
& -3.62 \mathrm{X}_{2}^{2}+5.00 \mathrm{X}_{1} * \mathrm{X}_{2} \\
\mathrm{Y}_{3}= & 98.43+3.17 \mathrm{X}_{1}+1.87 \mathrm{X}_{2}+1.54 \mathrm{X}_{1}^{2} \\
& -1.46 \mathrm{X}_{2}^{2}-0.60 \mathrm{X}_{1} * \mathrm{X}_{2} \\
\mathrm{Y}_{4}= & 4.41+0.41 \mathrm{X}_{1}+0.14 \mathrm{X}_{2}+0.38 \mathrm{X}_{1}^{2} \\
& -0.015 \mathrm{X}_{2}^{2}-0.092 \mathrm{X}_{1} * \mathrm{X}_{2} \\
\mathrm{Y}_{5}= & 5.83+0.33 \mathrm{X}_{1}+0.25 \mathrm{X}_{2}+0.10 \mathrm{X}_{1}^{2} \\
& -0.40 \mathrm{X}_{2}^{2}-1.17 \mathrm{X}_{1} * \mathrm{X}_{2}
\end{aligned}
$$

The positive coefficient for $\mathrm{X} 1$ and $\mathrm{X} 2$ in the equation indicates that the linear effect of SHD-DFP.

\subsection{Uncoded Value}

$$
\begin{aligned}
\mathrm{y}_{1}= & 0.261+0.085 \mathrm{X}_{1}+0.025 \mathrm{X}_{2}-2.758 \mathrm{X}_{1}^{2} \\
& -2.758 \mathrm{X}_{2}^{2}+2.509
\end{aligned}
$$

$$
\begin{aligned}
\mathrm{y}_{2}= & -22.57-0.456 \mathrm{X}_{1}-0.010 \mathrm{X}_{2}+2.455 \mathrm{X}_{1}^{2} \\
& -1.44 \mathrm{X}_{2}^{2}-2.00 \mathrm{X}_{1} * \mathrm{X}_{2} \\
\mathrm{y}_{3}= & 562.33-10.84 \mathrm{X}_{1}+3.82 \mathrm{X}_{2}+0.06 \mathrm{X}_{1}^{2} \\
& -0.06 \mathrm{X}_{2}^{2}-0.024 \mathrm{X}_{1} * \mathrm{X}_{2} \\
\mathrm{y}_{4}= & 131.59-2.804 \mathrm{X}_{1}+0.391 \mathrm{X}_{2}+0.015 \mathrm{X}_{1}^{2} \\
& -6.138 \mathrm{X}_{2}^{2}-3.700 \mathrm{X}_{1} * \mathrm{X}_{2} \\
\mathrm{y}_{5}= & 47.086-0.819 \mathrm{X}_{1}-0.866 \mathrm{X}_{2}+4.137 \mathrm{X}_{1}^{2} \\
& -0.016 \mathrm{X}_{2}^{2}-0.010 \mathrm{X}_{1} * \mathrm{X}_{2}
\end{aligned}
$$

The negative coefficient for $X_{1}$ in equation $Y_{2}, Y_{3}, Y_{4}$ and $Y_{5}$ while $X_{2}$ in equation $Y_{2}$ have the negative coefficient indicate that the linear effect of SHD-DFP.

The magnitude of P-value indicates that SHD-DFP have significant effect on all the responses at 5\% level. The quadratic terms have significant effect on overall acceptability at $5 \%$ level $(\mathrm{P}<0.05)$. The $3 \mathrm{D}$ response surface plot were generated for different interactions of any two independent variables, check holding the value of third variables as constant at the central level. The effect of $\mathrm{X}$ variables on the $\mathrm{Y}$ variable has shown in Figures 1-5.

\subsection{Criteria of Optimum Value for the Responses}

To consider all the responses simultaneously for optimization, the multiple regression was used to get compromise optimum conditions and it has found that the scores were 15.19, 1.52, 100.41, 5.14 and 7 for Diameter $(\mathrm{cm})$, Cooking time (min), Weight (g), Kneading time (min) and Overall acceptability respectively, corresponding to 


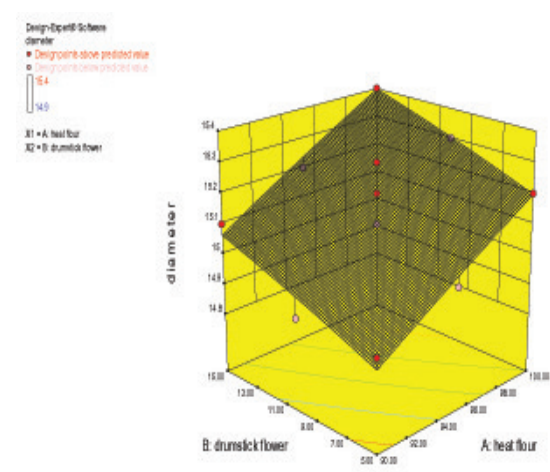

Figure 1. 3D effect of RSM for SHD-DFP on diameter.

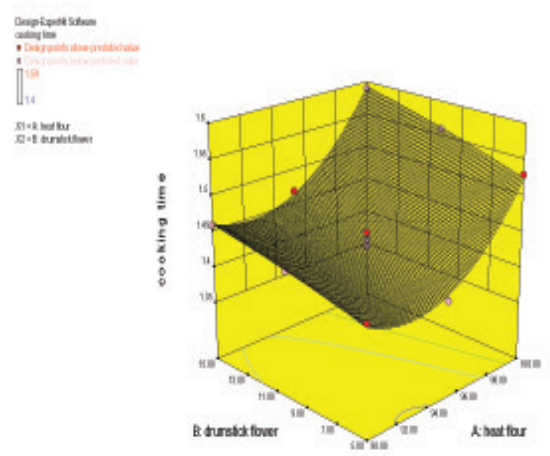

Figure 2. 3D effect of RSM for SHD-DFP on cooking time.

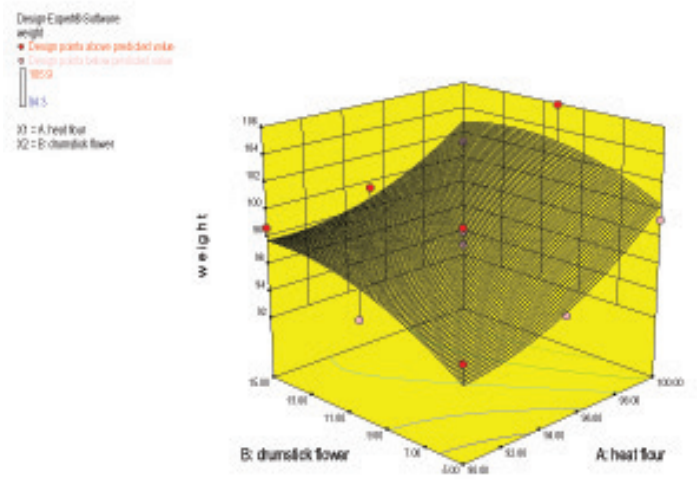

Figure 3. 3D effect of RSM for SHD-DFP on weight.

the optimum condition of wheat flour $100 \mathrm{gm}$ as $\mathrm{X}_{1}$ and shade dried drumstick flower powder $5 \mathrm{gm}$ as $\mathrm{X}_{2}$.

\subsection{Physical Properties of the Developed SHD-DFP Chappathi}

The physical properties of the SHD-DFP incorporated chappathi is shown in Table 4.

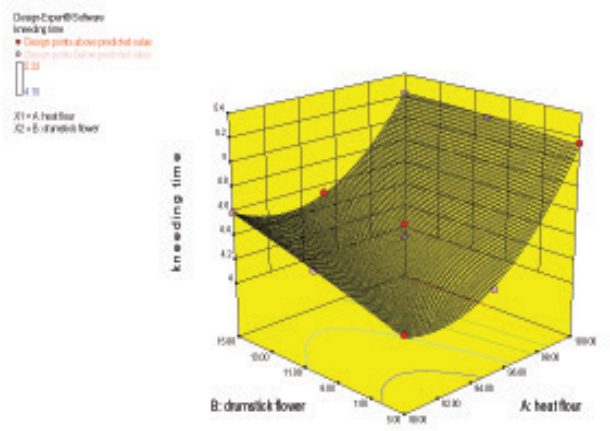

Figure 4. 3D effect of RSM for SHD-DFP on kneading time.
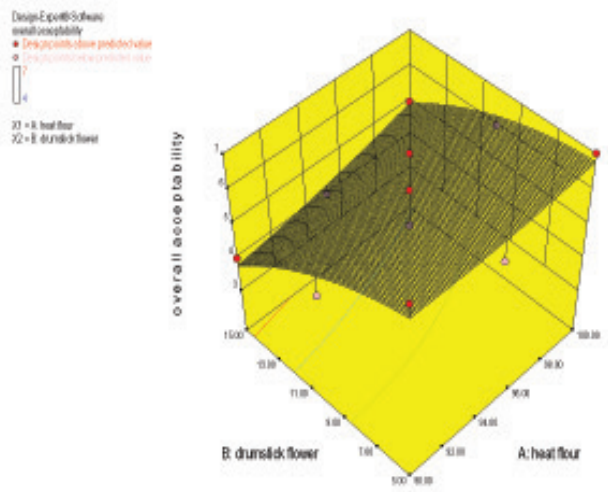

Figure 5. 3D effect of RSM for SHD-DFP on overall acceptability.

Among the thirteen variations of chappathi, $V_{9}$ has got the highest score of 15.36 and the least score 14.84 is obtained by $\mathrm{V}_{1}$ for the diameter. For the cooking time, the highest score 1.58 is obtained by variation $V_{9}$ which is followed by $\mathrm{V}_{6}$ with a score of 1.55 and the least score 1.40 is obtained by the variation $\mathrm{V}_{2}$. Regarding the weight attribute, the highest score 104.32 is obtained by the variation $\mathrm{V}_{6}$ which is followed by the variation $\mathrm{V}_{9}$ with a score of 101.26 and the least score 94.40 is obtained by the variation $\mathrm{V}_{4}$. For the kneading time attribute the highest score 5.28 is obtained by the variation $\mathrm{V}_{6}$. It is followed by the variation $\mathrm{V}_{3}$ with a score of 5.15 and the least score 4.14 is obtained by the variation $V_{1}$. Results of the Duncan's test reveal that there was significant difference for the variations.

\subsection{Organoleptic evaluation of SHD-DFP chappathi using Duncan's multiple range test}

Among 13 variables of chappathi, $\mathrm{V}_{1}$ and $\mathrm{V}_{11}$ have scored which is the highest score of 7.10 for appearance attri- 
Table 4. Physical properties of the developed SHD-DFP chappathi

\begin{tabular}{lcccc}
\hline Variables & Diameter & Cooking time & Weight & Kneading time \\
\hline $\mathrm{S}$ & $14.88 \pm 0.08$ & $1.41 \pm 0.01$ & $95.14 \pm 0.087$ & $4.12 \pm 0.01$ \\
$\mathrm{~V}_{1}$ & $14.84 \pm 0.55^{\mathrm{a}}$ & $1.41 \pm 0.00^{\mathrm{b}}$ & $94.30 \pm 0.070^{\mathrm{a}}$ & $4.14 \pm 0.01^{\mathrm{a}}$ \\
$\mathrm{V}_{2}$ & $15.00 \pm 0.07^{\mathrm{b}}$ & $1.40 \pm 0.01^{\mathrm{a}}$ & $94.70 \pm 0.070^{\mathrm{a}}$ & $4.21 \pm 0.01^{\mathrm{a}}$ \\
$\mathrm{V}_{3}$ & $15.16 \pm 0.05^{\mathrm{c}}$ & $1.52 \pm 0.01^{\mathrm{f}}$ & $99.38 \pm 0.083^{\mathrm{c}}$ & $5.15 \pm 0.01^{\mathrm{d}}$ \\
$\mathrm{V}_{4}$ & $14.90 \pm 0.07^{\mathrm{a}}$ & $1.43 \pm 0.00^{\mathrm{c}}$ & $94.40 \pm 0.100^{\mathrm{a}}$ & $4.36 \pm 0.01^{\mathrm{b}}$ \\
$\mathrm{V}_{5}$ & $15.08 \pm 0.08^{\mathrm{bc}}$ & $1.42 \pm 0.01^{\mathrm{b}}$ & $97.42 \pm 0.083^{\mathrm{b}}$ & $4.36 \pm 0.01^{\mathrm{b}}$ \\
$\mathrm{V}_{6}$ & $15.26 \pm 0.05^{\mathrm{d}}$ & $1.55 \pm 0.01^{\mathrm{g}}$ & $104.32 \pm 3.199^{\mathrm{e}}$ & $5.28 \pm 0.24^{\mathrm{e}}$ \\
$\mathrm{V}^{\mathrm{d}}$ & $15.08 \pm 0.08^{\mathrm{bc}}$ & $1.44 \pm 0.01^{\mathrm{d}}$ & $98.64 \pm 0.089^{\mathrm{bc}}$ & $4.56 \pm 0.01^{\mathrm{c}}$ \\
$\mathrm{V}_{8}$ & $15.12 \pm 0.08^{\mathrm{c}}$ & $1.47 \pm 0.01^{\mathrm{e}}$ & $99.58 \pm 0.083^{\mathrm{c}}$ & $4.53 \pm 0.01^{\mathrm{c}}$ \\
$\mathrm{V}_{9}$ & $15.36 \pm 0.05^{\mathrm{c}}$ & $1.58 \pm 0.01^{\mathrm{h}}$ & $101.26 \pm 0.114^{\mathrm{d}}$ & $5.23 \pm 0.01^{\mathrm{de}}$ \\
$\mathrm{V}_{10}$ & $15.12 \pm 0.08^{\mathrm{c}}$ & $1.43 \pm 0.00^{\mathrm{c}}$ & $98.38 \pm 0.083^{\mathrm{bc}}$ & $4.37 \pm 0.01^{\mathrm{b}}$ \\
$\mathrm{V}_{11}$ & $15.10 \pm 0.07^{\mathrm{bc}}$ & $1.44 \pm 0.01^{\mathrm{d}}$ & $98.62 \pm 0.083^{\mathrm{bc}}$ & $4.49 \pm 0.01^{\mathrm{c}}$ \\
$\mathrm{V}_{12}$ & $15.08 \pm 0.08^{\mathrm{bc}}$ & $1.43 \pm 0.11^{\mathrm{c}}$ & $98.38 \pm 0.083^{\mathrm{bc}}$ & $4.38 \pm 0.11^{\mathrm{b}}$ \\
$\mathrm{V}_{13}$ & $15.28 \pm 0.08^{\mathrm{de}}$ & $1.45 \pm 0.01^{\mathrm{d}}$ & $98.72 \pm 0.083^{\mathrm{c}}$ & $4.38 \pm 0.01^{\mathrm{b}}$ \\
$\mathrm{F}$ Value & 19.49 & 234.64 & 48.86 & 169.49 \\
$\mathrm{P}$ Value & 0.00 & 0.00 & 0.00 & 0.00 \\
\hline
\end{tabular}

Table 5. Mean organoleptic evaluation of SHD-DFP incorporated Chappathi using Duncan multiple range test

\begin{tabular}{lcccccc}
\hline Variables & Appearence & Colour & Flavour & Taste & Texture & $\begin{array}{c}\text { Overall } \\
\text { acceptability }\end{array}$ \\
\hline $\mathrm{S}$ & $6.45 \pm 0.73$ & $6.40 \pm 0.85$ & $6.00 \pm 0.81$ & $6.20 \pm 0.81$ & $6.60 \pm 0.51$ & $6.10 \pm 0.73$ \\
$\mathrm{~V}_{1}$ & $7.10 \pm 0.74^{\mathrm{a}}$ & $7.00 \pm 0.82^{\mathrm{a}}$ & $5.90 \pm 1.19^{\mathrm{a}}$ & $6.80 \pm 0.63^{\mathrm{bcd}}$ & $7.10 \pm 0.74^{\mathrm{c}}$ & $6.90 \pm 0.74^{\text {fgh }}$ \\
$\mathrm{V}_{2}$ & $6.40 \pm 0.96^{\mathrm{a}}$ & $7.00 \pm 0.67^{\mathrm{a}}$ & $6.00 \pm 0.82^{\mathrm{ab}}$ & $6.30 \pm 0.95^{\mathrm{abc}}$ & $6.10 \pm 0.74^{\mathrm{ab}}$ & $7.20 \pm 0.79^{\mathrm{h}}$ \\
$\mathrm{V}_{3}$ & $6.70 \pm 1.06^{\mathrm{a}}$ & $6.50 \pm 0.85^{\mathrm{a}}$ & $6.50 \pm 0.85^{\mathrm{abc}}$ & $6.00 \pm 0.82^{\mathrm{ab}}$ & $6.50 \pm 1.08^{\mathrm{abc}}$ & $6.70 \pm 0.82^{\text {fgh }}$ \\
$\mathrm{V}_{4}$ & $6.60 \pm 0.84^{\mathrm{a}}$ & $6.60 \pm 0.84^{\mathrm{a}}$ & $6.90 \pm 0.99^{\mathrm{bc}}$ & $5.80 \pm 0.63^{\mathrm{a}}$ & $6.40 \pm 0.97^{\mathrm{abc}}$ & $6.10 \pm 0.74^{\text {cdef }}$ \\
$\mathrm{V}_{5}$ & $6.80 \pm 1.03^{\mathrm{a}}$ & $7.00 \pm 0.82^{\mathrm{a}}$ & $6.50 \pm 1.08^{\mathrm{abc}}$ & $6.60 \pm 1.07^{\mathrm{abcd}}$ & $6.70 \pm 0.95^{\mathrm{abc}}$ & $5.40 \pm 0.84^{\mathrm{abc}}$ \\
$\mathrm{V}_{6}$ & $7.00 \pm 0.82^{\mathrm{a}}$ & $6.70 \pm 0.82^{\mathrm{a}}$ & $6.70 \pm 0.95^{\mathrm{abc}}$ & $7.10 \pm 0.74^{\mathrm{cd}}$ & $6.80 \pm 0.92^{\mathrm{abc}}$ & $5.90 \pm 0.74^{\text {cde }}$ \\
$\mathrm{V}_{7}$ & $7.00 \pm 0.66^{\mathrm{a}}$ & $7.10 \pm 0.74^{\mathrm{a}}$ & $6.90 \pm 0.57^{\mathrm{bc}}$ & $6.80 \pm 0.92^{\mathrm{bcd}}$ & $6.60 \pm 0.52^{\mathrm{abc}}$ & $5.00 \pm 1.05^{\mathrm{ab}}$ \\
$\mathrm{V}_{8}$ & $6.80 \pm 1.03^{\mathrm{a}}$ & $7.10 \pm 0.74^{\mathrm{a}}$ & $6.90 \pm 0.57^{\mathrm{bc}}$ & $7.20 \pm 0.79^{\mathrm{d}}$ & $5.90 \pm 0.99^{\mathrm{a}}$ & $5.60 \pm 0.97^{\mathrm{bcd}}$ \\
$\mathrm{V}_{9}$ & $6.60 \pm 0.96^{\mathrm{a}}$ & $6.60 \pm 0.97^{\mathrm{a}}$ & $6.80 \pm 0.79^{\mathrm{abc}}$ & $7.10 \pm 0.74^{\mathrm{cd}}$ & $6.30 \pm 0.95^{\mathrm{bc}}$ & $4.70 \pm 0.82^{\mathrm{a}}$ \\
$\mathrm{V}_{10}$ & $6.60 \pm 0.99^{\mathrm{a}}$ & $6.60 \pm 0.84^{\mathrm{a}}$ & $6.60 \pm 0.84^{\mathrm{abc}}$ & $6.90 \pm 0.74^{\mathrm{cd}}$ & $6.90 \pm 0.99^{\mathrm{abc}}$ & $6.20 \pm 0.63^{\mathrm{defg}}$ \\
$\mathrm{V}_{11}$ & $6.80 \pm 0.92^{\mathrm{a}}$ & $7.00 \pm 0.67^{\mathrm{a}}$ & $6.60 \pm 0.97^{\mathrm{abc}}$ & $6.60 \pm 0.84^{\mathrm{abcd}}$ & $6.60 \pm 0.97^{\mathrm{abc}}$ & $7.00 \pm 0.67^{\mathrm{gh}}$ \\
$\mathrm{V}_{12}$ & $7.10 \pm 0.82^{\mathrm{a}}$ & $6.60 \pm 0.97^{\mathrm{a}}$ & $7.00 \pm 0.82^{\mathrm{c}}$ & $7.10 \pm 0.74^{\mathrm{cd}}$ & $6.70 \pm 0.95^{\mathrm{abc}}$ & $6.80 \pm 0.63^{\mathrm{fgh}}$ \\
$\mathrm{V}_{13}$ & $6.80 \pm 0.88^{\mathrm{a}}$ & $6.70 \pm 0.82^{\mathrm{a}}$ & $6.40 \pm 0.84^{\mathrm{abc}}$ & $6.90 \pm 0.99^{\mathrm{cd}}$ & $7.10 \pm 0.74^{\mathrm{c}}$ & $6.50 \pm 0.85^{\text {fgh }}$ \\
$\mathrm{F}_{\text {Value }}$ & 0.61 & 0.76 & 1.48 & 2.82 & 1.58 & 9.87 \\
$\mathrm{P}_{\text {Value }}$ & 0.83 & 0.69 & 0.14 & 0.00 & 0.10 & 0.00 \\
\hline
\end{tabular}

bute followed by $\mathrm{V}_{6}$ and $\mathrm{V}_{7}$ with a score of 7.00. For the colour attribute, the highest score 7.10 obtained by the variation $\mathrm{V}_{7}$ and $\mathrm{V}_{8}$ which is followed by $\mathrm{V}_{1}$ and $\mathrm{V}_{2}$ with a score of 7.00 and the least score 6.50 is obtained by the variation $\mathrm{V}_{3}$. Regarding he flavor attribute, the highest score 7.00 is obtained by the variation $\mathrm{V}_{12}$ which is followed by the variation $\mathrm{V}_{4}, \mathrm{~V}_{7}$ and $\mathrm{V}_{8}$ with a score of 6.90 and the least score 5.90 is obtained by the variation $\mathrm{V}_{1}$. For the taste attribute, the height score 7.20 is obtained by the variation $\mathrm{V}_{8}$ and is followed by the variation $\mathrm{V}_{6}, \mathrm{~V}_{9}$ and $\mathrm{V}_{12}$ with a score of 7.10 and the least score of 5.80 is obtained by the variation $\mathrm{V}_{4}$. Regarding the texture attribute, the highest score 7.10 is obtained by the variation $V_{1}$ and $V_{13}$ which is followed by the variation $\mathrm{V}_{10}$ with a score of 6.90 and the least score 5.90 is obtained by the variation $\mathrm{V}_{8}$. Regarding overall acceptability attribute, the highest score 7.20 is obtained by the variation $\mathrm{V}_{2}$ which is followed by the variation $\mathrm{V}_{1}$ with a score of 6.90 and the least score 5.00 is obtained by the variation $\mathrm{V}_{7}$. Results of the Duncan's test reveal that there was significant difference for the variations as shown in Table 5. 


\section{Conclusion}

It is concluded that RSM was used successfully to optimize the level of wheat flour and SHD-DFP for the development of chappathi. The overall acceptable chappathi with less kneading time, cooking time and more diameter and weight of the chappathi can be prepared using the combination of wheat flour $100 \mathrm{~g}$ and SHD-DFP $5 \mathrm{~g}$.

\section{References}

1. Siddhuraju P., and Becker K., "Antioxidant properties of various solvent extracts of total phenolic constituents from three different agroclimatic origins of drumstick tree (Moringa oleifera Lam.) leaves", J. Agr. Food Chem., vol. 51, p. 2144-2212, 2003.

2. Vanisha N., Sharma K., and Gandhi H., "Food based approach to combat vitamin A deficiency", UGC-DSA Monograph Series No. 3. Department of Foods and Nutrition, M.S. University of Baroda, Vadodara 390002, 2005.

3. Murakami A., Kitazono Y., Jiwajinda S., Koshimizu K., and Ohigashi H., "Niaziminin, a thiocarbamate from the leaves of Moringa oleifera, holds a strict structural requirement for inhibition of tumor-promoter- induced Epstein", Pubmed, vol. 64(4), p. 319-23, 1998.

4. Singh K.K., and Kumar K., "Ethnotherapeutics of some medicinal plants used as antipyretic agents among the tribals of India". Journal of Economic and Taxonomic Botany, vol. 23(1), p. 135-141, 2001.

5. Lakshmi, and Radha, "Incorperation of dehydrated plantain and drumstick flowers into recipes and their acceptability", The Ind. J. Nutr. Dietet, vol. 42, p. 300, 2005.

6. Sidhu, and Scribel, "Effect of flour milling conditions on the quality of Indian unleavened flat bread(chappathi)", J. Fd. Sci., vol. 53, p. 1563-1565, 1998.

7. Box G. E. P., Hunter W. G., Hunter J. S., Statistics for experimenters-an introduction to design, data analysis and model building, John wiley and sons, N.Y., 1978.

8. Myers J. P., vom Saal F. S., Akingbemi B. T., Arizono K., Belcher S., Colborn T. "Why public health agencies cannot depend on Good Laboratory Practices as a criterion for selecting data: the case of bisphenol", A. Environ. Health Perspect., vol. 117, p. 309-315, 2009.
9. Ranganna. Handbook of analysis and quality control for fruit and vegetable products, $2^{\text {nd }}$ edn, Tata McGraw Hill Publ Co, New Delhi, 1986.

10. Sathe S.K., Dephande S.S., Salunkhe D.K., "Functional properties of lupin protein concentrate". J. Food Sci., vol. 47, p. 491-497, 1982.

11. Ige M.T., "Measurement of some parameters affecting the handling losses of some varieties of cowpea", Agric. Eng. Res., vol. 22, p. 127-133, 1984.

12. AOAC, Methods of analysis of the Association of Official Analytical Chemists. $15^{\text {th }}$ edition, Washington DC. USA, 1990.

13. Nazni P. and Gracia J. "Optimization Of sun-dried Moringa Olifera flower powder incorporated Chappathi using response surface methodology", International Journal of Current Research, vol. 9, p. 050-057, 2010.

14. Khuri A. L., and Cornell J. A., Response Surfaces Design and Analysis, Marcel Dekker Inc, New York, 5, 1997.

15. Gacula Jr M. C., Singh J. "Statistical methods in food consumer research", New York; Academic Press, Inc., p. 214-272, 1991.

16. Wanasaundara, and Shahidi. "Optimization of hexametaphosphate assisted extraction of flaxseed proteins using response surface methodology". J. Food Sci. 61, 1996.

17. SPSS. "Statistical package for Social Sciences for indos Release 16", LEAD Technologies, 2007.

18. Murray P. D., McGavern D. B., Sathornsumetees S., and Rodriguez M., "Spontaneous remyelination following extensive demyelination is associated with improved neurological function in a viral model of multiple sclerosis" Brain, vol. 124 (Pt 7), p. 1403-16, 2001.

19. Sneddecor G.W., Cochran W.G. Statistical methods. $8^{\text {th }}$ edition, Affiliated East West Press, Iowa State Univ Press, USA, 1994.

20. Jayaraman K.S., Gupta D.K., Rao N.B. "Quality characteristics of some vegetables dried and indirect sun drying", Indian Food Packer, vol. 45(1), p. 16-23, 1991.

21. Singh U., Sagar V. R., Behera T. K., Kumar P. S. Effect of drying conditions on the quality of dehydrated selected leafy vegetables, Indian Agricultural Research Institiute, New Delhi, India, 2006.

22. Fagbemi T. N., Oshodi A. A., Ipinmoroti K. O. "Effects of processing on the functional properties of full fat and defatted fluted pumpkin (Telfairia occidentalis) seed flour", J. Food Technol., vol. 4, p. 70-79, 2006. 